\title{
Using the Balanced Scorecard: Both Common And Unique Measures Are Informative
}

\author{
Margaret L. Gagne, (Email: margaret.gagne@ marist.edu), Marist College \\ Joan Hollister, (Email: joan.hollister@marist.edu), Marist College \\ Gregory J. Tully, (Email: greg.tully@marist.edu), Marist College
}

\begin{abstract}
The balanced scorecard (BSC), developed by Kaplan and Norton (1992), allows an organization to translate its strategy and objectives into a series of performance measures. A recent study by Lipe and Salterio (2000) found that subjects use common scorecard measures in performance evaluation but disregard unique measures. This study finds that both common and unique scorecard measures are used in performance evaluation.
\end{abstract}

\section{INTRODUCTION}

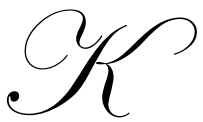

aplan and Norton (1992) developed the balanced scorecard (BSC) as a means of translating an organization's strategy and objectives into a series of performance measures. Over the past decade, the BSC concept has become well accepted as an approach for using diverse measures for performance assessment. Lipe and Salterio (2000) cast doubt on whether management actually considers the entire set of BSC performance measures. Based on a study of the use of the BSC, they concluded that when making performance evaluations, managers disregard measures that are unique to particular divisions. In contrast, this study finds that subjects' performance evaluations are sensitive to variations in unique measures, as well as common measures.

\section{THE BALANCED SCORECARD AND COMPARATIVE PERFORMANCE EVALUATIONS}

The balanced scorecard (BSC) is a method both for communicating an organization's strategic objectives and for strategic performance measurement. Accordingly, BSC measures are based on the critical success factors that an organization has identified as essential for the realization of its strategy. As originally organized by Kaplan and Norton (1992), the BSC provides a balanced view of strategic performance because its measures reflect four key perspectives on strategic performance: financial, customer relations, internal business processes, and learning and growth. (Example BSCs can be found in the appendix. Table 1 lists the measures used for the two divisions in the study. The following paragraphs use these examples as illustrations.) Dissemination of a BSC throughout an organization emphasizes the underlying critical success factors, focuses management attention on their attainment, and, thereby, enhances the prospects for strategic success.

Having established the BSC approach for an organization as a whole, the process cascades throughout the organization. Strategic business units within the organization develop their own BSCs reflecting their derivative strategic objectives. As a result of being members of the same organization, some of the measures will be the same across business units and are identified as common measures. For example, in the BSCs presented in the appendix, RadWear and WorkWear divisions have two financial measures which are the same: return on sales and sales growth. The company as a whole, GJP Inc., has identified sales generation as an important part of their strategy. Similarly, RadWear and WorkWear share the same customer related measures of repeat sales and customer satisfaction rating. Returns to suppliers and average markdowns are the common internal business process measures. 
$\underline{1}$

The learning and growth common measures which RadWear and WorkWear share are hours of employee training per employee and the number of employee suggestions per employee. The common measures among the divisions reflect areas identified as important for the organization overall. The study by L\&S found these measures to be important in their subjects' performance evaluations.

Because business units differ both in their strategic responsibilities and in their critical business processes, some of the measures on their individual BSCs will vary correspondingly. The measures, which differ across business units, are identified as unique measures. Referring to the Table1 (or appendix), RadWear has new store sales and sales dollars per square foot as financial measures whereas WorkWear has Sales dollars per visit and catalog sales. The measures differ because the divisions have different environments and different divisional strategies. The use of different performance measures for different business units is inherent in the BSC approach to strategic management and the assessment of strategic performance. Use of the BSC methodology involves comparative evaluations of business units based, at least in part, on measures that differ from unit to unit.

\section{A DISTURBING FINDING BY LIPE AND SALTERIO (L \& S)}

Businesses routinely make comparative performance evaluations to allocate resources, assess managerial performance, and adjust business strategies. Existing research on how the inclusion of both common and unique measures inherent in a BSC regime affects comparative performance evaluations is limited. Slovic and MacPhillamy (1974) find that judges underweight or ignore unique cues relative to common cues in a nonbusiness setting. Lipe and Salterio (2000) (L\&S) extend these earlier findings to performance evaluations based on BSC information. In the L\&S study, subjects respond to the common measures, but ignore the information provided by unique BSC measures. L\&S' findings are important, and troubling, because unique measures lie at the heart of the BSC concept of strategic performance evaluation.

What do these findings imply for strategic performance evaluation regimes such as the BSC? L\&S conclude that their findings have two major implications (p.293). The first implication is that if unique measures are disregarded in ex post performance evaluation, then they are also more likely to be disregarded in ex ante decision making. Second, because unique measures tend to be leading indicators and common measures lagging indicators (Kaplan and Norton 1996), evaluators may be focusing on lagging, rather than leading indicators. Both of these effects, if validated, threaten the strategic success of the firm, and, if left uncorrected, undermine the strategic benefits claimed for the BSC by its proponents.

The BSC approach is important to strategic performance measurement (Atkinson et al. 1997). A study estimated that about 40 percent of the Fortune 1000 companies had implemented the BSC by the end of 2000 (Sullivan 2001). Given the widespread attention and acceptance afforded the BSC in recent years (Silk, 1998), findings that indicate systematic judgmental biases in the use of BSC measures must be taken quite seriously.

\section{ANOTHER LOOK: UNIQUE MEASURES ARE USED}

L\&S presented BSC information to subjects by stating both the actual and target performance for each measure in the divisional scorecards. The deviations from target averaged approximately $6.5 \%$ above target for the low performance conditions, and approximately $10.6 \%$ above target for the high performance conditions. Note first, that the magnitude of the differences between performance conditions was usually only around $4 \%$, and, second, that performance was above target on all measures for each of two divisions. In this study, the differences in the performance levels are much larger and can be below the target as well as above

It is possible that it was the relatively small variations in the unique measures in L\&S which caused the measures to be ignored. Because the measures are unique to each division, it takes more effort to interpret the implications of the differences in the measures. The subjects perhaps were unwilling or unable to deal with these small differences 
A second characteristic of the L\&S manipulation that merits further investigation is the relationship between the actual and targeted performance of the divisions. In all of the L\&S performance conditions, the divisions exceeded the BSC benchmark performance goals. Goals are fundamental to the understanding of individual performance, task satisfaction, and performance appraisal (Locke and Latham 1990):

... goals define for the individual what an acceptable level of performance or direction of action is. Actions that fall short of desired ends are appraised as unsatisfactory (Bandura, 1988) and lead to negative performance evaluations and/or self-evaluations. ... Actions that attain or exceed desired ends lead to positive appraisals. (p. 87)

Subjects' performance evaluations may reflect this goal-centered orientation and may result in the use of a "makingthe-numbers" heuristic. Behavior consistent with a making-the-numbers orientation is frequently mentioned in literature addressing behavioral aspects of control and performance evaluation. For example, managers' anticipation of a making-the-numbers orientation is cited as a cause of both ex ante manipulations of budgetary slack, and ex post biasing (Hilton 1999, Simons 2000). It is also cited as the cause of the adverse motivational consequences resulting from the use of ideal rather than reasonably attainable standards as the basis for performance benchmarks (Merchant 1998, Hilton 1999, Simons 2000). This study restates the same BSC measures used in the L\&S study so that goals were exceeded in the high performance conditions (actual is $20 \%$ above target), but not in the low performance conditions (actual is $20 \%$ below target).

In summary, this study, building on the L\&S findings, is designed to test the use of both common and unique measures from a BSC in assessing the performance of division managers. The actual performance differs from the target performance by a substantial 20 percent. Also, the actual performance can be below as well as above the target performance.

The basic design of the experiment and the discussion above yield the following hypotheses stated in the alternative form.

$\mathbf{H}_{\mathbf{A}} \mathbf{1}$ : Performance evaluations using the balanced scorecard will be higher when common measures are favorable relative to the target than when the common measures are unfavorable relative to the target.

$\mathbf{H}_{\mathrm{A}} \mathbf{2}$ : Performance evaluations using the balanced scorecard will be higher when unique measures are favorable relative to the target than when the unique measures are unfavorable relative to the target.

\section{METHOD}

\section{Overview}

Except for certain modifications in the experimental design required to address the changes in size and direction of the deviations from target, the experiment followed the published materials and procedures of L\&S as closely as possible. This was our strategy for several reasons. First, we want the focus of this study to be on the changes we discussed and not on differences in the materials or procedures. Second, L\&S (2000, pp. 291-292) invested considerable time and effort in developing and validating the BSC measures employed in their study. So, given our desire for comparability, it was strictly to our advantage to adopt these performance measures.

To examine the judgmental effects of common versus unique BSC measures on comparative performance evaluations, L\&S used a case scenario of a firm specializing in women's apparel. They provided subjects with the BSCs for two divisions, which the subjects used to rate the performance of each division's manager. The divisions' scorecards showed sixteen measures, four from each of the four BSC perspectives. Within each perspective, two common measures and two unique measures reported the performance of each division. L\&S state that their case follows the Kenyon Stores example in Kaplan and Norton (1996). 


\section{$\underline{1}$}

\section{Procedures}

Prior to participating in the BSC judgment task for this study, subjects completed an introductory reading on the BSC (Kaplan and Norton 1992), discussed the BSC, and completed an exercise in BSC construction. This was done to provide subjects with a common degree of familiarity with BSC concepts. No mention was made of the distinction between common and unique measures or the possible impact of that distinction on BSC judgments. Upon arriving at the experiment, subjects were welcomed, thanked for their participation, and assured that there were no correct answers to the questions they were to be asked. The experiment then proceeded as follows:

- $\quad$ subjects read a brief introductory scenario detailing the strategic situations of the two operating divisions using the BSC,

- $\quad$ examined the first division's BSC and evaluated that manager's performance using L\&S' 100 point scale, then did the same for the second division,

- completed a post-experimental questionnaire that elicited information pertaining to experimental validity, demographic data, and the subject's use of BSC information in the performance evaluations.

A complete set of experimental materials appears in Appendix A. Table 1 lists the performance measures employed in the study identifying them as common to both divisions' BSCs, unique to the RadWear division, or unique to the WorkWear division.

\begin{tabular}{|c|c|c|}
\hline \multicolumn{3}{|l|}{$\begin{array}{c}\text { Table 1 } \\
\text { Balanced Scorecard Measures Employed }\end{array}$} \\
\hline Measure Identity & Type & Measure Set \\
\hline \multicolumn{3}{|l|}{ Financial Measures } \\
\hline Return on Sales (net income as a \% of sales) & common & both \\
\hline Sales growth (\% change over last year) & common & both \\
\hline New store sales (as a \% of total sales) & unique & RadWear \\
\hline Sales dollars per square foot of retail space & unique & RadWear \\
\hline Sales dollars per visit & unique & WorkWear \\
\hline Catalog sales (as a \% of total sales) & unique & WorkWear \\
\hline \multicolumn{3}{|l|}{ Customer Related Measures } \\
\hline Customer satisfaction rating (on a scale of 0 to 100 ) & common & both \\
\hline Repeat sales (sales to existing customers as a \% of total sales) & common & both \\
\hline Mystery shopper program rating (on a scale of 0 to 100$)$ & unique & RadWear \\
\hline Returns by customers as a \% of sales & unique & RadWear \\
\hline $\begin{array}{l}\text { Percentage increase in captured customers (customers for whom this company is the } \\
\text { sole supplier) }\end{array}$ & unique & WorkWear \\
\hline Referrals per month & unique & WorkWear \\
\hline \multicolumn{3}{|l|}{ Internal Business Process Measures } \\
\hline Returns to suppliers (as a \% of purchases) & common & both \\
\hline Average markdowns (as a \% of total sales) & common & both \\
\hline Average major brand names per store & unique & RadWear \\
\hline Sales from new merchandise lines (as a \% of total sales) & unique & RadWear \\
\hline Orders filled within one week (as a \% of total orders) & unique & WorkWear \\
\hline Catalog orders filled with errors (as a \% of total orders) & unique & WorkWear \\
\hline \multicolumn{3}{|l|}{ Learning and Growth Measures } \\
\hline Employee suggestions per employee & common & both \\
\hline Hours of employee training per employee & common & both \\
\hline Average tenure of sales personnel in years & unique & RadWear \\
\hline Stores computerized (as a \% of total stores) & unique & RadWear \\
\hline Percentage of sales managers with MBA degrees & unique & WorkWear \\
\hline Database certification of personnel (as a \% of total number of personnel) & unique & WorkWear \\
\hline
\end{tabular}


$\underline{1}$

The common and unique measures each take on one of two possible values: High or Low. For each subject these values are the same for both divisions. Therefore, for any given subject,

- RadWear and WorkWear BSCs differ only in the identities of the unique performance measures reported on their scorecards.

- $\quad$ RadWear and WorkWear BSCs never differ in the levels of either the common or the unique performance measures relative to the BSC target.

The complete experimental design is summarized in Table 2.

\begin{tabular}{|c|c|c|c|}
\hline \multicolumn{4}{|c|}{$\begin{array}{c}\text { Table 2 } \\
\text { Complete Experimental Design }\end{array}$} \\
\hline \multirow{2}{*}{$\begin{array}{c}\text { Between Subjects } \\
\text { Variables }\end{array}$} & \multicolumn{2}{c|}{$\begin{array}{c}\text { Within Subjects Variable } \\
\text { Repeated Measure }\end{array}$} \\
\hline \multirow{3}{*}{$\begin{array}{c}\text { Common } \\
\text { Measure Level }\end{array}$} & $\begin{array}{c}\text { Unique } \\
\text { Measure Level }\end{array}$ & \multicolumn{2}{c|}{$\begin{array}{c}\text { Division - Unique Measures Identities } \\
\text { RadWear }\end{array}$} \\
\cline { 2 - 4 } High & High & $\begin{array}{c}\text { Common: } 20 \% \text { above target } \\
\text { Unique: } 20 \% \text { above target }\end{array}$ & $\begin{array}{c}\text { Common: } 20 \% \text { above target } \\
\text { Unique: } 20 \% \text { above target }\end{array}$ \\
\cline { 2 - 4 } & Low & $\begin{array}{c}\text { Common: } 20 \% \text { above target } \\
\text { Unique: } 20 \% \text { below target }\end{array}$ & $\begin{array}{c}\text { Common: } 20 \% \text { above target } \\
\text { Unique: } 20 \% \text { below target }\end{array}$ \\
\hline \multirow{3}{*}{ Low } & High & $\begin{array}{c}\text { Common: } 20 \% \text { below target } \\
\text { Unique: } 20 \% \text { above target }\end{array}$ & $\begin{array}{c}\text { Common: } 20 \% \text { below target } \\
\text { Unique: } 20 \% \text { above target }\end{array}$ \\
\cline { 2 - 4 } & Low & $\begin{array}{c}\text { Common: } 20 \% \text { below target } \\
\text { Unique: } 20 \% \text { below target }\end{array}$ & $\begin{array}{c}\text { Common: } 20 \% \text { below target } \\
\text { Unique: } 20 \% \text { below target }\end{array}$ \\
\hline
\end{tabular}

\section{Subjects}

The subject pool consisted of 24 MBA students and 16 senior accounting majors, all of whom had been exposed to basic information concerning the balanced scorecard. They were provided with descriptions of the two divisions used and were asked to evaluate the managers of the two divisions on a scale of 1 to 100. Two subjects provided unusable responses, which were excluded from the statistical analysis.

\section{RESULTS}

This section first presents the results of tests designed to check the validity of the experimental manipulations. Next, the tests of the specific hypotheses are presented and discussed.

The first four items of the post-experimental questionnaire (Appendix A) address the clarity of the instructions, the clarity of the other materials used in the experiment, the understandability of the specific BSC performance measures used in the experiment, and the clarity of the performance evaluation task. Subjects responded to each of these items using a five-point scale to rate their agreement with an assertion of clarity or understandability. A response of " 1 " signifies strong agreement with the assertion; "5" signifies strong disagreement with the assertion; and "3" signifies subjects' neutrality (neither agreement nor disagreement). The hypothesis for each item, in alternate form is as follows:

\section{$\mathbf{H}_{\mathrm{A}}: \quad$ mean response $<3$,}

which would indicate agreement or strong agreement with the assertion. For each item, the hypothesis was supported statistically ( $\mathrm{t}$ values with maximum p-value $<0.0005$ ). Thus, subjects' understood clearly both the judgment situation that they were in and the materials that operationalized the experimental conditions. There were no 
$\underline{1}$

significant differences between the responses of the MBA students and the senior accounting majors to these items.

Table 3, Panel A provides the mean performance evaluations in each combination of experimental conditions, as well as the marginal and grand means. Inspection of these means reveals that they are intuitively sensible. The highest mean evaluation occurs when all the performance measures are above the target. Likewise, the lowest evaluation occurs when all the measures are below target. Mean evaluations for intermediate conditions, in which some measures are above target and some are below, fall between these extremes. Statistical results (Table 3, Panel B) indicate that subjects' performance evaluations were significantly affected by the manipulations.

\begin{tabular}{|c|c|c|c|}
\hline \multicolumn{3}{|c|}{$\begin{array}{c}\text { Table 3 } \\
\text { Panel A } \\
\text { Mean Performance Evaluations by Experimental Condition - Divisions Combined }\end{array}$} \\
\cline { 2 - 4 } Unique Level \\
\hline \multicolumn{2}{|c|}{\begin{tabular}{c} 
Low \\
Average \\
\hline Common \\
Level
\end{tabular}$\quad$ High } & 70.2 & 80.6 \\
\hline High & 91.0 & 68.8 & 71.9 \\
\hline Low & 75.0 & 69.5 & 76.3 \\
\hline Average & 83.0 & & \\
\hline
\end{tabular}

\begin{tabular}{|c|c|c|c|c|c|}
\hline \multicolumn{6}{|c|}{$\begin{array}{c}\text { Table 3 } \\
\text { Panel B } \\
\text { Effects of Experimental Manipulations on Subjects' Performance Evaluations }\end{array}$} \\
\hline Source & Sum of Squares & df & Mean Square & $\mathbf{F}$ & Sig. \\
\hline Common & 1420.422 & 1 & 1420.422 & 3.916 & .056 \\
\hline Unique & 3448.896 & 1 & 3448.896 & 9.510 & .004 \\
\hline Common * Unique & 1021.264 & 1 & 1021.264 & 2.816 & .103 \\
\hline Error & 12331.050 & 34 & 362.678 & & \\
\hline
\end{tabular}

\section{Hypothesis 1}

Hypothesis 1 addresses the effect of variations in the level of the common measures on performance evaluations. This manipulation was operationalized as the factor, "Common." As hypothesized, mean performance evaluations are significantly higher when the common measures are above target or "High" than when they are below target or "Low". In summary, the first hypothesis, that performance evaluations will be higher when common measures are above target, is supported by the results.

\section{Hypothesis 2}

Hypothesis 2 pertains to the effect of variations in the levels of the unique measures on performance evaluations. This manipulation was operationalized as the factor, "Unique." Note that this factor has nothing to do with the effects, if any, of any specific differences between the sets of unique measures provided on the BSCs for the RadWear and WorkWear divisions. The unique factor effect pertains only to the average (across divisions) effect of variations in the levels of the unique measures. As hypothesized, subjects' mean performance evaluations are significantly higher when the unique measures are above target or "High", than when they are below target or "Low". Further, the effect of varying the level of the unique measures is greater than that associated with changes in the level of the common measures. This indicates that there is no evidence that subjects' evaluations underweight unique measures relative to common measures. This test provides evidence that subjects do not ignore the information provided by unique measures.

\section{CONCLUDING DISCUSSION}

The conclusions of this study are as follows: Our subjects' performance evaluations responded systematically to variations in the levels of both the common and the unique BSC measures and we found no evidence 
$\underline{1}$

that subjects underweighted unique measures relative to common measures; the response of performance evaluations to variations in the levels of the unique measures is at least as large as that for variations in the common measures. Given that L\&S' subjects' performance evaluations did not respond to variations in the same unique measures used in this study, it is important to consider the possible causes and implications of the disparity between the findings of the two studies.

This study was designed to determine whether unique measures would be used for performance evaluation when results were 20 percent above or below target. L\&S's results were always above target and the deviation was never as great as $20 \%$. Clearly any disparity in the findings of the two studies would be attributable to the intentional and systematic differences in the tasks that were operationalized. Given our use of L\&S' published materials, one can reasonably conclude that the tasks operationalized in the studies are very similar except for the differences in the magnitude of the performance variations between the two divisions, and differences in the divisions' attainment of their BSC goals. Thus, it is likely that one or both of these differences caused the disparity in the findings. While our findings do not address which of these two changes caused the disparity or whether it was both changes operating in combination, the overall result that unique measures are used is of fundamental importance.

The L\&S' study is the beginning of a research initiative (Kaplan and Norton, 2001). Their finding that unique measures were not used was a disturbing one that challenged the premise underlying the balanced scorecard as a management tool. This study refutes their claim and supports the credibility of the balanced scorecard approach.

The authors acknowledge Ron Gagne for invaluable assistance in gathering the experimental data, Professor Robert Walsh for help in obtaining subjects, and the participants in the Marist College, School of Management faculty research seminar for their helpful comments.

\section{REFERENCES}

1. Atkinson, A. A., R. Balakrishnan, P. Booth, J. M. Cote, T. Groot, T. Malmi, H. Roberts, E. Uliana, and A. Wu. 1997. New directions in management accounting research. Journal of Management Accounting Research 9: 70-108.

2. Hilton, R. 1999. Management Accounting, 4th edition, Irwin-McGraw-Hill, Inc.

3. Kaplan, R. and D. Norton. 1992. The balanced scorecard-Measures that drive performance. Harvard Business Review 70 (1): 71-79.

4. Kaplan, R. and D. Norton. 1996. The Balanced Scorecard. Boston, MA: Harvard Business School Press.

5. Kaplan, R. and D. Norton. 2001. Transforming the balanced scorecard from performance measurement to strategic management: Part II. Accounting Horizons Vol. 15, No. 2, June 2001, p. 159.

6. Lipe, Marlys G. and Steven E. Salterio. 2000. The balanced scorecard: judgmental effects of common and unique performance measures. The Accounting Review. (July 2000): 283-298.

7. Locke, E. A. and G. P. Latham. 1990. A Theory of Goal Setting and Task Performance. Englewood Cliffs, NJ: Prentice Hall.

8. Merchant, K. A. (1998) Modern Management Control Systems. New Jersey: Prentice-Hall.

9. Silk, S. 1998. Automating the balanced scorecard. Management Accounting 79(11): 38-42.

10. Simons, R. 2000. Performance Measurement \& Control Systems for Implementing Strategy. Upper Saddle River, NJ: Prentice Hall.

11. Slovic, P. and D. MacPhillamy. 1974. Dimensional commensurability and cue utilization in comparative judgment. Organizational Behavior and Human Performance 11: 172-194.

12. Sullivan, T. 2001. Scorecard Eases Businesses' Balancing Act. InfoWorld 2001. January 8, 2001. 


\section{APPENDIX}

\section{Instructions}

Please read the following Case Scenario. After you feel comfortable with this material, go to the division scorecards to rate each division manager. Finally, go to the Questionnaire to submit your results.

Thank you,

\section{Professors}

\section{Case Scenario}

GJP Incorporated is a preeminent U.S. clothing retailer, made up of 8 divisions, that together achieve about $\$ 12$ billion in annual sales. Historically, the individual divisions operated independently with little central coordination or integration. After attending an executive roundtable that featured the Balanced Scorecard, GJP's CEO decided to implement the Balanced Scorecard approach throughout the company. She was convinced that the Balanced Scorecard's emphasis on the use of multiple performance measures could play a key role in helping the company achieve significant internal growth.

- In line with what she had learned about the Balance Scorecard, the CEO established a team of upper level management to first clarify the firm's overall mission and goals, and then to determine specific objectives and the strategy to achieve the objectives. Finally, a set of measures that captured the strategy was developed. This set of measures is the organization's Balanced Scorecard.

- $\quad$ The next step was to have each division define its own division-level strategy, in line with the company-wide strategy. Each division also was to determine its own set of measures for evaluation. The measures chosen for an individual division's Balanced Scorecard were to be in line with what that particular division needed to accomplish in order to achieve the division level strategy.

- $\quad$ The Balanced Scorecards have now been in place for a year. You are the upper level manager charged with the overall evaluation of GJP's two largest divisions, RadWear and WorkWear. RadWear is a retail division specializing in clothing for the urban teenager. WorkWear sells business uniforms through direct sales contacts with business clients.

- $\quad$ RadWear's management determined that its growth must take place through an aggressive strategy of opening new stores. RadWear also determined that it must increase the number of brands offered to keep the attention and capture the clothing dollars of its teenage customers.

- $\quad$ Although WorkWear has historically focused on women's clothing, WorkWear's management decided to increase its sales by including a few basic uniforms for men. It is expected that this will make WorkWear a more attractive supplier for businesses that want to purchase uniforms from a single supplier. WorkWear also decided to print a catalog so that clients could place some orders without a direct sales visit, particularly for repeat or replacement orders; this should help to retain some sales which might otherwise be lost due to time considerations. 
You should now proceed to the Scorecards:

\begin{tabular}{|c|c|c|}
\hline \multicolumn{3}{|c|}{$\begin{array}{c}\text { RadWear's Balanced Scorecard } \\
\text { Except for measures reported in italics, a higher score is better. }\end{array}$} \\
\hline Measure & $\begin{array}{l}\text { Target } \\
\text { Score }\end{array}$ & $\begin{array}{l}\text { Actual } \\
\text { Score }\end{array}$ \\
\hline \multicolumn{3}{|c|}{ Financial Measures } \\
\hline Return on Sales (net income as a \% of sales) & 24 & 29 \\
\hline New store sales (as a \% of total sales) & 30 & 24 \\
\hline Sales growth (\% change over last year) & 35 & 42 \\
\hline Sales dollars per square foot of retail space & 80 & 64 \\
\hline \multicolumn{3}{|c|}{ Customer Related Measures } \\
\hline Mystery shopper program rating (on a scale of 0 to 100 ) & 82 & 66 \\
\hline Repeat sales (sales to existing customers as a \% of total sales) & 30 & 36 \\
\hline Returns by customers as a \% of sales & 12 & 14 \\
\hline Customer satisfaction rating (on a scale of 0 to 100 ) & 83 & 100 \\
\hline \multicolumn{3}{|c|}{ Internal Business Process Measures } \\
\hline Returns to suppliers (as a \% of purchases) & 6 & 5 \\
\hline Average major brand names per store & 32 & 26 \\
\hline Average markdowns (as a \% of total sales) & 16 & 13 \\
\hline Sales from new merchandise lines (as a \% of total sales) & 25 & 20 \\
\hline \multicolumn{3}{|c|}{$\begin{array}{r}\text { Learning and Growth Measures } \\
\end{array}$} \\
\hline Average tenure of sales personnel in years & 1.4 & 1.0 \\
\hline Hours of employee training per employee & 15 & 18 \\
\hline Stores computerized (as a \% of total stores) & 85 & 68 \\
\hline Employee suggestions per employee & 3.3 & 4.0 \\
\hline
\end{tabular}

Decide now how you would rate the manager of this division. You will be required to enter a single number between 0 [worst] to 100 [best] on the questionnaire at the end of this process to reflect your assessment. You will also be asked about what factors influenced your rating.

\begin{tabular}{|c|c|c|}
\hline \multicolumn{3}{|l|}{$\begin{array}{c}\text { WorkWear's Balanced Scorecard } \\
\text { Except for measures reported in italics, a higher score is better. }\end{array}$} \\
\hline Measure & $\begin{array}{l}\text { Target } \\
\text { Score }\end{array}$ & $\begin{array}{c}\text { Actual } \\
\text { Score }\end{array}$ \\
\hline \multicolumn{3}{|l|}{ Financial Measures } \\
\hline Return on Sales (net income as a \% of sales) & 24 & 29 \\
\hline Sales dollars per visit & 175 & 140 \\
\hline Sales growth (\% change over last year) & 35 & 42 \\
\hline Catalog sales (as a \% of total sales) & 20 & 16 \\
\hline \multicolumn{3}{|l|}{ Customer Related Measures } \\
\hline Percentage increase in captured customers (customers for whom this company is the sole supplier) & 10 & 8 \\
\hline Repeat sales (sales to existing customers as a \% of total sales) & 30 & 36 \\
\hline Referrals per month & 120 & 96 \\
\hline Customer satisfaction rating (on a scale of 0 to 100 ) & 83 & 100 \\
\hline \multicolumn{3}{|l|}{ Internal Business Process Measures } \\
\hline Returns to suppliers (as a \% of purchases) & 6 & 5 \\
\hline Orders filled within one week (as a \% of total orders) & 80 & 64 \\
\hline Average markdowns (as a \% of total sales) & 16 & 13 \\
\hline Catalog orders filled with errors (as a \% of total orders) & 8 & 10 \\
\hline \multicolumn{3}{|l|}{ Learning and Growth Measures } \\
\hline Percentage of sales managers with MBA degrees & 60 & 48 \\
\hline Hours of employee training per employee & 15 & 18 \\
\hline
\end{tabular}




\begin{tabular}{|l|c|c|}
\hline$\underline{\mathbf{I}}$ & 70 & 56 \\
\hline Database certification of personnel (as a \% of total number of personnel) & 3.3 & 4.0 \\
\hline
\end{tabular}

Decide now how you would rate the manager of this division. You will be required to enter a single number between 0 [worst] to 100 [best] on the questionnaire at the end of this process to reflect your assessment. You will also be asked about what factors influenced your rating.

\section{Manager Rating Questionnaire}

\section{$\underline{\text { RadWear Division }}$}

Please rate the performance of the manager of the RadWear Division on the line below. Enter a single number between 0 [worst] to 100 [best] on the line below to reflect your assessment of the RadWear manager's performance.

My rating of the RadWear manager is

\section{WorkWear Division}

Please rate the performance of the manager of the WorkWear Division on the line below. Enter a single number between 0 [worst] to 100 [best] on the line below to reflect your assessment of the WorkWear manager's performance.

My rating of the WorkWear manager is

\section{Post Judgment Questionnaire}

Consider each of the questions below carefully, then circle the best answer for each.

1. The instructions for this exercise are clear.

\begin{tabular}{lllr}
1 & 2 & 3 & \multicolumn{1}{c}{4} \\
strongly agree & neither & $\begin{array}{l}\text { disagree strongly } \\
\text { agree or } \\
\text { disagree }\end{array}$ & disagree
\end{tabular}

If you answered 3, 4, or 5, please help us by explaining briefly.

2. The other materials used in this exercise are clear.

\begin{tabular}{lllr}
1 & 2 & 3 & \multicolumn{1}{c}{4} \\
strongly agree & neither & $\begin{array}{l}\text { disagree strongly } \\
\text { agree or } \\
\text { disagree }\end{array}$ & disagree
\end{tabular}

If you answered 3, 4, or 5, please help us by explaining briefly. 
3. The specific performance measures provided in this exercise are understandable.

\begin{tabular}{|c|c|c|c|}
\hline & & 3 & 4 \\
\hline $\begin{array}{l}\text { strongly agree } \\
\text { agree }\end{array}$ & neither & $\begin{array}{l}\text { disagree strongly } \\
\text { agree or } \\
\text { disagree }\end{array}$ & disagree \\
\hline
\end{tabular}

If you answered 3, 4, or 5, please help us by explaining briefly.

4. The judgments that you were asked to make were clear to you.

\begin{tabular}{|c|c|c|c|}
\hline 1 & & thes & 4 \\
\hline $\begin{array}{l}\text { strongly agree } \\
\text { agree }\end{array}$ & neither & $\begin{array}{l}\text { disagree strongly } \\
\text { agree or } \\
\text { disagree }\end{array}$ & disagree \\
\hline
\end{tabular}

If you answered 3, 4, or 5, please help us by explaining briefly.

5. In your ratings of the division managers' performance, to what degree did you rely on the measures of financial performance?

$\begin{array}{lccc}1 & 2 & 3 & 4 \\ \text { ignored/ } & \text { somewhat } & \text { important } & \text { relied on } \\ \text { no } & \text { important } & & \text { exclusively } \\ \text { reliance } & & & \end{array}$

6. In your ratings of the division managers' performance, to what degree did you rely on the customer related measures of performance?

$\begin{array}{lccc}1 & 2 & 3 & 4 \\ \text { ignored/ } & \text { somewhat } & \text { important } & \text { relied on } \\ \text { no } & \text { important } & & \text { exclusively } \\ \text { reliance } & & & \end{array}$

7. In your ratings of the division managers' performance, to what degree did you rely on the measures of performance related to internal business processes?

$\begin{array}{lccc}1 & 2 & 3 & 4 \\ \text { ignored/ } & \text { somewhat } & \text { important } & \text { relied on } \\ \text { no } & \text { important } & & \text { exclusively } \\ \text { reliance } & & & \end{array}$


$\underline{1}$

8. In your ratings of the division managers' performance, to what degree did you rely on the measures of performance related to learning and growth?

$\begin{array}{llcc}1 & 2 & 3 & 4 \\ \text { ignored/ } & \text { somewhat } & \text { important } & \text { relied on } \\ \text { no } & \text { important } & & \text { exclusively } \\ \text { reliance } & & & \end{array}$

9. Select from the list below your area of primary professional experience and expertise.

Accounting
Finance
Human resources
General management
Marketing/Sales
Operations or manufacturing
Other (Please specify ___

10. How many years of professional experience do you have? years.

11. Check off the academic degrees you have earned on the list below.

Bachelors degree (B.S., B.A., etc.)

Masters degree (M.S., M.A., etc.)

Doctoral degree (Ph.D., Ed.D., etc.)

12. In your professional career, have you ever used Balanced Scorecard type performance measures (i.e. evaluations using several different performance measures) to evaluate multiple organizational units (departments, divisions, shifts, etc.) under your supervision?

Yes.

No.

If you answered "Yes." please help us by explaining briefly.

The performance measures listed in the table below were provided to you as a basis for assessing the performance of the manager of the RadWear Division. Carefully rate each measure according to the degree of importance or reliance that you gave each measure in assessing the performance of the RadWear Manager.

Use the following rating scale:

$$
\begin{aligned}
& 1=\text { ignored } / \text { no reliance } \\
& 2=\text { somewhat important } \\
& 3=\text { important } \\
& 4=\text { relied on exclusively }
\end{aligned}
$$




\section{RadWear's Balanced Scorecard}

\begin{tabular}{|l|l|}
\hline \multicolumn{1}{|c|}{ Measure } & Degree of Reliance \\
\hline Return on Sales (net income as a \% of sales) & \\
\hline Average markdowns (as a \% of total sales) & \\
\hline Stores computerized (as a \% of total stores) & \\
\hline Sales dollars per square foot of retail space & \\
\hline Customer satisfaction rating (on a scale of 0 to 100) & \\
\hline Average tenure of sales personnel in years & \\
\hline Employee suggestions per employee & \\
\hline Sales growth (\% change over last year) & \\
\hline Repeat sales (sales to existing customers as a \% of total sales) & \\
\hline Returns to suppliers (as a \% of purchases) & \\
\hline New store sales (as a \% of total sales) & \\
\hline Average major brand names per store & \\
\hline Hours of employee training per employee & \\
\hline Mystery shopper program rating (on a scale of 0 to 100) & \\
\hline Returns by customers as a \% of sales & \\
\hline Sales from new merchandise lines (as a \% of total sales) & \\
\hline
\end{tabular}

The performance measures listed in the table below were provided to you as a basis for assessing the performance of the manager of the WorkWear Division. Carefully rate each measure according to the degree of importance or reliance that you gave each measure in assessing the performance of the WorkWear Manager.

Use the following rating scale:

$1=$ ignored / no reliance

2 = somewhat important

$3=$ important

$4=$ relied on exclusively

WorkWear's Balanced Scorecard

\begin{tabular}{|l|l|}
\hline \multicolumn{1}{|c|}{ Measure } & Degree of Reliance \\
\hline Average markdowns (as a \% of total sales) & \\
\hline Repeat sales (sales to existing customers as a \% of total sales) & \\
\hline Employee suggestions per employee & \\
\hline Referrals per month & \\
\hline Percentage of sales managers with MBA degrees & \\
\hline Database certification of personnel (as a \% of total number of personnel) & \\
\hline Orders filled within one week (as a \% of total orders) & \\
\hline Sales growth (\% change over last year) & \\
\hline Returns to suppliers (as a \% of purchases) & \\
\hline Customer satisfaction rating (on a scale of 0 to 100) & \\
\hline Catalog sales (as a \% of total sales) & \\
\hline Catalog orders filled with errors (as a \% of total orders) & \\
\hline Hours of employee training per employee & \\
\hline $\begin{array}{l}\text { Percentage increase in captured customers (customers for whom this company is the sole } \\
\text { supplier) }\end{array}$ & \\
\hline Sales dollars per visit & \\
\hline Return on Sales (net income as a \% of sales) & \\
\hline
\end{tabular}


$\underline{1}$

NOTES 